\title{
INSTRUMENTS "PAYABLE AT" A BANK
}

\author{
ROsCOE STEFFEN*
}

THE PRACTICE of drawing notes "payable at" a bank, like that of accepting bills of exchange in that fashion, is probably more

1 than two hundred years old. ${ }^{x}$ As such, it goes back almost to the beginning of commercial banking in England. ${ }^{2}$ But, even so, it has never been quite clear whether the commercial community regarded "payable at" as in some sense a drawing upon the maker's or acceptor's account with the bank named, like a check or draft, or merely as the designation of a convenient place where the parties might "attend," to make payment or to dicker for a renewal. Makers and acceptors, or their lawyers, have blown both hot and cold depending, it would seem, on which view was at the moment most to their advantage, and, as might be expected, the courts have reached diverse results. It is time, therefore, in the new Commercial Code, ${ }^{3}$ to spell out one contract or the other or some compromise and set the matter at rest.

The problem is sharply presented in one aspect by Section 87 of the NII which provides that where an instrument "is made payable at a bank it is equivalent to an order to the bank to pay the same for the account of the principal debtor thereon." This would appear to be an adoption of the check view. Hence it would follow, according to NIL Section I86, that, should the holder delay presentment unduly, any loss occasioned by failure of the bank would be put upon the holder. ${ }^{4}$ However, the statute also provides, NII Section 70 , that where an instrument is made payable at a special place and the maker or acceptor "is able and willing to pay it there at maturity, such ability and willingness are equivalent to a tender

* John P. Wilsọn Professor of Law, University of Chicago Law School.

I Note, for example, Bishop v. Chitty, 2 Strange IIO5 (I743).

2 Checks came into use during the last years of the seventeenth century. Consult Bischop, Rise of the London Money Market 55 (I9IO).

${ }^{3}$ Following many years of work the Commissioners on Uniform State Laws and the American Law Institute have prepared a redraft of the Uniform Negotiable Instruments Law and other commercial statutes. It is expected that a final draft will be completed by next spring, to be known as the Uniform Commercial Code. References to the Uniform Commercial Code are to the Spring, I950 tentative draft and will be abbreviated UCC in the footnotes.

4 NIL $\S$ I86, Rule Where Instrument Payable at Bank. "A check must be presented for payment within a reasonable time after its issue or the drawer will be discharged from liability thereon to the extent of the loss caused by the delay." 
of payment on his part." 5 And it is said to follow from this, according to common-law decisions relating to tender, that the only loss to a dilatory holder would be interest, costs and possibly attorney's fees. ${ }^{6}$ Loss due to bank failure would be for the maker or acceptor to bear; in fact he would be charged with interest and costs unless he could pay the face amount of the obligation into court when suit is brought. ${ }^{7}$

The solution proposed in the latest draft of the Commercial Code is something less than helpful. Two provisions are offered: Alternative $A$ says that "a note or acceptance which states that it is payable at a bank is the equivalent of a bill drawn on the bank payable when it falls due out of any funds of the maker or acceptor in current account or otherwise available for such payment"; Alternative $B$ provides the converse: "[A] note or acceptance which states that it is payable at a bank is not of itself an order or authorization to the bank to pay it." Each state is graciously invited to take its choice. Moreover, there is no attempt, apparently, in the counterpart of NIL Section 70 , or elsewhere in the Code, to follow through on either one pattern or the other. The draftsman, it would seem, has simply thrown up his hands, figuratively speaking.

Of course, there may be extenuating circumstances. Four states, Illinois, Kansas, Nebraska and South Dakota, refused to adopt NIL Section 87; three states, Georgia, Minnesota and West Virginia adopted it in reverse; only one, North Dakota, has repealed it; Idaho has made it optional with the bank; and two, Missouri and New Jersey, limit the authority to the day of maturity only. ${ }^{9}$ Counting noses, however, it is still true that forty states have found the Section in its present form, or with minor changes, to be a livable provision. Since a clear majority favors the present section, it would seem that it, or the modified Alternative $A$, should accordingly be recommended for uniform adoption.

But the draftsman further points out that, as might be expected, a difference in "commercial and banking practice" exists in different parts of the country. In eastern states, where NIL Section 87 is in effect, banks

$s$ NIL $\S$ 7o, Effect of Want of Demand on Principal Debtor. "Presentment for payment is not necessary in order to charge the person primarily liable on the instrument; but if the instrument is, by its terms, payable at a special place, and he is able and willing to pay it there at maturity, such ability and willingness are equivalent to $a$ tender of payment upon his part. But except as herein otherwise provided, presentment for payment is necessary in order to charge the drawer and indorsers."

${ }^{6}$ See Binghampton Pharmacy v. First Nat'l Bank, ז3x Tenn. 7rr, I76 S.W. 1038 (I915)'

7 Hills v. Place, 48 N.Y. 520 (1872).

${ }^{8}$ UCC \& 3-122, Instruments Payable at Bank.

9 For statutory citations see Brannan's Neg. Inst. Law 43 (Beutel's 5th ed., 1932). 
customarily pay notes and acceptances domiciled with them without asking for further instructions. In western and southern states, on the other hand, "the bank's only function is to notify the maker or acceptor that the instrument has been presented and to ask for his instructions." Moreover, "both practices are well established" and we are warned that a change "might lead to undesirable consequences for holders, banks or depositors." Finally we are told there is "no great need for uniformity" anyway, since "the instruments involved are chiefly promissory notes, which infrequently cross state lines." ism, rather too neatly stated. Surely the dictum that east is east and west is west, if ever true, does not apply in commercial matters.

Of course if the draftsman were right that there is no need for uniformity, there would be no need for either version of NIL Section 87. It would be better to omit all reference to the problem in the Code. But one suspects the writer of the comment of merely trying to put a good face on what at first blush, at least, is an unsatisfactory proposal. The fact is that notes in large numbers cross state lines-if that is the test-as do bills of exchange, and that most of the latter, like the former, are today customarily payable at a bank. ${ }^{\text {Ix }}$ Such being the case, it becomes very important to holders to know what is required by way of presentment and what are the consequences of a failure to meet the statutory requirement. Clearly this is a proper subject for uniform legislation.

As for the threat of "undesirable consequences" to follow any change in practice, the writer is not particularly impressed. In the first place, what exactly are the undesirable consequences? Secondly, perhaps a change in practice would be a good thing, if in fact a change is necessary. Actually when one dissects the Texas farmer or banker-I am told-he is found to function in much the same way as does the New York banker or farmer. In what follows, therefore, it is proposed first to examine how the legal rules concerning instruments payable at a bank have grown up, assessing as far as possible their effect upon practice, and second to suggest in terms of consequences what rules should be adopted in the Code. It may be that when the situation is seen as a whole, much of the apparent conflict will disappear.

so UCC \& 3-r22, Comment, at 3rg.

II Millions of dollars of short term notes, most of which cross state lines many times, are in circulation. The rates for such paper are quoted daily in the financial section of the N.Y. Times. A considerable volume of customer's paper also still finds its way from the country banker to his city correspondent. All of this paper and more is today made payable as a matter of course at some banker's place of business. 


\section{The Eardy ENVIronMENT}

The customary method of settling money obligations in England even as late as I 700 was at best a cumbersome one. It was still generally necessary, as appears from Ward v. Evans, ${ }^{12}$ for debtor and creditor, or their servants, to repair to a goldsmith-banker, where the debtor would arrange for credit and the banker would pay out coin or bank notes to the creditor. It was a time-consuming operation, but safer than the earlier practice of paying from cash kept in a strong box. Obviously the bank check, which was introduced at about this time, was a necessary invention. ${ }^{{ }^{3}}$ Debtors might thereby make "conditional payment" of their obligations at any time and place with safety, and creditors could suit their own convenience within the bounds of "due diligence" in demanding their money from the drawee bank. The invention though extremely useful was probably not patentable, for it was merely the adaptation of an old device, the bill of exchange, to a new use. ${ }^{\text {I4 }}$

It would not be accurate to say that the law relating to bills of exchange was applied to checks without modification. Perhaps this was so during the eighteenth century, as there are singularly few reported cases concerning checks in that period. But by 1800 competing concepts were being urged. Indeed, the notion that a check is merely an informal authority to pay-not a negotiable instrument-persisted in some quarters until recently. ${ }^{\mathrm{xs}}$ The principal question, though, concerned the drawer's contract. Two main differences were found. It was incumbent upon the holder to present his check with greater diligence, which meant by the next day after it was received, a much stricter rule than applied to bills..$^{16}$ But the drawer was never to be completely discharged, as in the case of a bill, by the holder's mere failure to make diligent presentment. Discharge for late presentment occurred only when the drawer suffered loss by the delay.

Some of the reasoning behind this development was brought out by

${ }^{12} 2$ Raymond 928 ( 1702 ).

${ }^{23}$ One of the earliest cases dealing with checks is Grant v. Vaughan, 3 Bur. 1516 (I764), where Lord Mansfield refers to the instrument in suit as a "cash-note" upon a banker.

I4 Consult, if curious, I Walker, Patents 226 et seq. (Deller's ed., x937).

xs It was still being argued in England as late as 1860 when in Keene v. Beard, 8 Com. B. R. (N.S.) 372 , the court held that an indorser of a check assumed the same obligation as the indorser of a bill.

${ }^{16}$ The "law" regarded checks and goldsmiths' notes very clearly as the same thing. In Manwaring v. Harrison, I Strange 508 (172r), the question of the time for presentment was left to the jury and they "declared it as their opinion, that a person who did not demand a goldsmith's note in two days, took the credit on himself." Note further East-India Co. v. Chitty, 2 Strange $1 \times 75$ ( 1742$)$. 
Mr. Justice Story in the case of In the matter of Broum..$^{17}$ There he quoted Chancellor Kent with full approval to this effect: "The drawer of a check is not a surety, but the principal, as much as the maker of a promissory note. The check is the acknowledgment of a certain sum due. It is an absolute appropriation of so much money in the hands of his banker to the holder of the check, and there it ought to remain until called for, and unless the drawer actually suffers by the delay, as by the intermediate failure of his banker, he has no reason to complain of delay not unreasonably protracted." This was said in order to contrast the situation of an indorser or, equally, of a drawer of an accepted bill, who, as a surety, has "a right to require diligence on the part of the holder, to relieve him from responsibility." 18 In the case of the drawer of a check, on the other hand, as Story points out, "if, by reason of the want of due presentment or want of due notice of dishonor, he is to be totally exonerated, he pockets both the original consideration and his funds in the hands of the bank or banker."

This reasoning is obviously vulnerable today, since the mere drawing of a check is not regarded as an appropriation or assignment of funds with the banker. ${ }^{20}$ Nor in the case of the bill of exchange is any distinction made between drawers and indorsers with respect to the necessity for presentment and notice of dishonor. ${ }^{2 x}$ Whether accepted or not, failure to meet the stated requirements apparently results in complete discharge. ${ }^{22}$ Why then should the drawer of a check not be discharged completely by a delay in presentment as is the drawer of a bill of exchange? Or, since he is a principal debtor, why should he be discharged at all? The answer probably lies in another place, the notion that a check is ordinarily not given in absolute payment, but as conditional payment only. That is to say, the check is regarded as being in some sense merely a security for the debt or underlying obligation of the drawer, and as such, on familiar principles, must be demanded promptly.

The view that checks and other paper given by a debtor to his creditor are but conditional payment is deeply rooted. Indeed, Lord Holt was quite certain, as usual, that even bank notes were not payment, except

${ }_{17} 2$ Story 502,4 Fed. Cas. 342 (C.C. Mass., 1843 ).

${ }^{18}$ Ibid., at 5 I3.

${ }^{29}$ Ibid., at $5 \mathbf{5 7}$.

${ }^{20} \mathrm{NIL} \$ \S \mathrm{I27,}$ I89.

${ }^{2 x} \mathrm{NIL} \S 70$, quoted note 5 supra.

${ }^{22}$ See Bridges v. Berry, 3 Taunt. I30 (C.P., I8ro). There is doubt though, whether the drawer of an unaccepted bill should be completely discharged for nonpayment. Actually his situation is much the same as that of a drawer of a check. See Chalmers, Bills of Exchange 370 (roth ed., I932), also Kessler, Ferguson, and Levi, Some Aspects of Payment by Negotiable Instrumerits, 45 Yale L. J. 1073 (1936). 
provisionally: "I am of opinion, and always was (notwithstanding the noise and cry, that it is the use of Lombard-street, as if the contrary opinion would blow up Lombard-street) that the acceptance of such a note is not actual payment." ${ }^{\prime 23}$ Of course bank notes have long since become money, and hence payment, but the books are full of cases until well into the nineteenth century stating the degree of diligence which creditors must employ in presenting such paper, under penalty of having "made it their own" in case of loss due to failure of the bank of issue.

The law concerning presentment of bank checks, developed with equal strictness, and for the same reasons. ${ }^{24}$ The holder having been given the means to obtain payment in money, would be guilty of "laches" if he did not proceed with diligence. It was even the rule as late as 1842 in England that the holder might not take the additional time required, even though only one day, for presentment through a collecting banker. ${ }^{25}$ While this has long since been relaxed to permit use of usual banking machinery, ${ }^{26}$ probably no rule is better settled today than that where drawer, drawee and payee are in the same place, presentment (or deposit for collection) must be made on the next business day following receipt of the item, or the drawer will be discharged - and his underlying obligation will be paid - to the extent of the loss suffered by the delay. ${ }^{27}$ In other words the contract of the drawer of a check, as spelled out in Section I86 of the NII, is little more than a codification of the rules regarding conditional payment.

\section{THE Formative Years}

During the early I800's notes and acceptances payable at a bank came before the English courts in a series of hard fought cases. The question presented was initially one of pleading: Was it necessary for a holder as part of his case to prove a presentment at the bank named? Of course it was clear, as it is today, that in order to charge secondary parties, i.e.

23 Ward v. Evans, 2 Raymond 928, 930 (I702).

24 It was decided in Beeching v. Gower, I Holt (N.P.) $3 \mathrm{I}_{3}$ (I8I6) that the holder of a bank note had acted with sufficient diligence in mailing it for payment on the second day, to either of the two stated places of payment, though one was more distant than the other. It was ruled in the same case that, by failing to mail a check by that time, the plaintiffs had been "guilty of laches" and "must suffer for their negligence." Ibid., at 316 .

2s Alexander v. Burchfield, 7 Man. \& Gr. IO6I (C.P., I842).

${ }^{6}$ See Heywood v. Pickering, [I874] g Q. B. 429; Joerns Bros. Mfg. Co. v. Burns, I73 Minn. 389, 217 N.W. 506 (1928), discussed in Turner, Bank Collections-The Direct Routing Practice, 39 Yale L. J. 468 (r930).

${ }_{27}$ McFadden Bros. Agency v. Keesee, I79 Ark. 510, I6 S.W. 2d 994 (I929); Republic Metalware Co. v. Smith, 218 Ill. App. I30 (r920), noted in 4 Ill. L.Q. I42 (ro22). 
drawers and indorsers, such a presentment was necessary. ${ }^{28}$ The issue being litigated, however, was whether an acceptor or maker could avail himself of the same defence. The next question, whether in case of loss the holder's delay in making presentment at the named bank should work a complete or partial discharge, or none at all, was left largely in the realm of dictum, as was the question of whether making an instrument so payable constituted an authority to the banker to pay.

The case of Sanderson v. Bowes ${ }^{29}$ was one of the first important authorities. Suit was brought by the holder upon a bearer bank note for $£$ I Is. which had been issued by defendant bankers payable upon demand at their banking house at Workington. Defendants demurred upon the ground that there had been no demand at the place of payment stated in the note. It was argued, however, that upon a contract of this nature it was not necessary to allege a special request, either as to time or place, since the action itself was a sufficient demand as against the maker. But Lord Ellenborough was of a different opinion, and sustained the demurrer: "[H]ere the duty is to be performed, and the money is made payable, at a specific place, viz. the defendant's banking-house, at Workington. Under such circumstances a demand there by the holder is a condition precedent, in order to give himself a title to receive the money." 30 Moreover, "it would be very inconvenient that the makers of notes of this description should be liable to answer them everywhere, when it is notorious that they have made provisions for them at a particular place, where only they engage to pay them."'3x

The result is still good law in England. In fact it has been generalized to apply not only to bankers' paper payable at their own places of business, but to any instrument where the maker, in the body of his note, has made it payable at a particular place. In such case, "it must be presented for payment at that place in order to render the maker liable." ${ }_{32}$ Indeed, the reasoning back of Sanderson $v$. Bowes is still persuasive in this country, in spite of NIL Section 70 , at least when confined to similar facts. That is to say, there is respectable authority to the effect that a demand for payment must be made at a banker's place of business before recovery may be had against him upon a certificate of deposit. ${ }^{33}$ And while this is

${ }^{88}$ Ambrose v. Hopwood, 2 Taunt. 60 (r809). Compare NIL $\$ 73$.

${ }^{29}$ I4 East 500 (C.P., I8II).

32 Ibid., at 508.

30 Ibid., at 507. ${ }^{32}$ Bills of Exchange Act $\$ 87$.

33 Elliott v. Capital City State Bank, I28 Iowa 275, I03 N.W. 777 (1905); cf. Gould v. Bank of Independence, 264 Ky. 5 II, 94 S.W. (2d) 991 (1936). The new Code, $\$ 3^{-x} 23$, adopts this position. 
usually put upon the ground that otherwise the banker might unconscionably plead the statute of limitations against a slow but innocent depositor, it may well proceed as much upon the reason of convenience, both to banker and to courts, advanced by Lord Ellenborough. Why should not a holder at least bestir himself sufficiently to demand payment at the place provided before taking his case to court?

The problem became more complicated when in Callaghan v. Aylett ${ }^{34}$ it was further decided by the Court of Common Pleas that the holder of a time bill, which had been accepted by the defendants payable at Messrs. Ramsbottoms, bankers, London, might not recover without proof that the bill had been presented at the place where by the acceptance it was made payable. The court said: "[D]oubtless there may be a qualified acceptance of a bill, which the holder is not bound to receive, but if he acquiesces in it, he must conform to the terms of it." ${ }^{35}$ This placed Lord Ellenborough "in an anxious situation," as he said in Fenton v. Goundry, ${ }^{36}$ a case on similar facts in the same year before the Kings Bench. Nevertheless this time Lord Ellenborough decided that no presentment was necessary: "I have always understood that an acceptance, though stated to be payable at a certain house of trade, binds the party to pay the bill generally and universally; and that there is no occasion to make a demand at the particular place in order to found the right of action on the bill, but that the action itself is a demand upon the party sued." 37

A distinction between the two cases might have been made, perhaps, upon the ground that in one the paper was payable at a bankers, in the other, at a house of trade.$^{38}$ But no such distinction was taken. The controversy finally reached the House of Lords in Rowe v. Young, ${ }^{39}$ which was an action by holder against acceptor upon a bill addressed to the drawee at Torpoint and accepted payable at Sir John Perring \& Co., bankers, London. Again no presentment was alleged or proved. Lord Eldon decided to ask the opinion of the twelve judges of the Kings Bench before giving his opinion and they decided, eight-to-four, that no presentment was necessary to charge the acceptor but, seven-to-five, that the acceptance was qualified. Lord Eldon agreed with the minority on the first question. And, though he was undoubtedly moved by the inconvenience to an acceptor who had made provision for payment at one place being

34 Taunt. 397 (C.P., I8Ir).

${ }^{36}$ I3 East 459 (K.B., I8II).

35 Ibid., at 399 .

37 Ibid., at 469 .

${ }^{38}$ The bill in the Fenton case was accepted payable at "C. Sikes, Snaith, and Co." who, for all that appeared, may have been tavern keepers, as Bayley, J., pointed out at 472.

39 2 Brod. \& Bing. 165 (C.P., r820). 
required to pay at another, $4^{40}$ he purported to decide purely as a matter of "law." Such an acceptance is "a contract to pay at Sir John Perrings and Co.," as written, and not generally.4r

It was further Lord Eldon's opinion that his decision would not be "of the least consequence to the commercial world," since it would be easy to adopt words to show a contrary meaning, if that was what the parties intended. But the commercial world must have thought otherwise, for next year it was provided by statute that an acceptance payable at a bankers is a "general acceptance," unless stated to be payable there and not elsewhere. ${ }^{42}$ The effect of this was twofold. First, and most obviously, presentment would not be necessary at the stated place of payment in order to recover of the acceptor. Such clearly is the English and American law today. ${ }^{43}$ Secondly, there could no longer be any argument that such an acceptance was qualified, and thus have the effect of discharging secondary parties. This too is law today. ${ }^{44}$ But it will be noted that nothing in the statute or in the prior case law necessarily reached the question whether a holder might not owe some obligation to make presentment at the place specified, or be found guilty of laches.

The point, however, had not gone unnoticed. In his advisory opinion in Rowe v. Young, ${ }^{45}$ it was stated very clearly by Judge Best, as common ground, that an acceptance payable at a bankers "is treated by all bankers as a draft on them or order to pay the bill so accepted." ${ }^{6}$ Moreover, while he saw no distinction between making a note payable at a bankers and accepting a bill so payable, since in both cases the words formed a part of the original contract, he did not regard a failure to present as working a complete discharge of the maker or acceptor. At most it was a matter of defense: "[T]he acceptor, if he would avail himself of the non-presentment of the bill, must show by his plea, that he was ready at the time and place of payment to take it up, but that the holder did not attend; and must

40 The critical situation was posed of a person who may have accepted a bill "payable at Calcutta," and made provision for it there, but who might be arrested for nonpayment in England.

42 Brod. \& Bing. 165,177 (C.P., I820).

42 I \& 2 Geo. IV, c. 78, \& I, enacts that "if any person shall accept a bill of exchange payable at the house of a banker or other place, without further expression in his acceptance, such acceptance shall be deemed . . . a general acceptance of such bill; but if the acceptor shall in his acceptance express that he accepts the bill payable at a banker's house or other place only, and not otherwise or elsewhere, such acceptance shall be deemed ... a qualified acceptance of such bill." See Halstead v. Skelton, 5 Adol. \& El. 86, II4 Eng. R. Ir80 (Q.B., I843). It was thus for the person from Calcutta to protect himself, not the converse.
13 BEA $\S 52 ;$ NIL $\S 70$.
452 Brod. \& Bing. 165 (C.P., I820).
$44 \mathrm{BEA} \S 44 ; \mathrm{NIL} \S \mathrm{r} 42$.
${ }_{4}^{6}$ Ibid., at $186-87$. 
bring the amount of the bill into court." And, in event the banker should fail, the holder further would "subject himself to the same consequences as one who keeps any other draft or a banker's check, beyond the day after that on which it was delivered to him..." 47 That is to say, the maker or acceptor would be discharged at least to the extent of the loss due to the holder's delay.

The idea was not new that by making an instrument payable at a bank the maker in effect writes a check upon his banker to pay the holder of the note or acceptance. In the early case of Bishop v. Chitty,,$^{48}$ the acceptor had written, "Messieurs Caswall and Mount, pay this bill when due for Thomas Chitty." The bill fell due on January 2, I74I. The bankers paid until the Igth; payment was not demanded until the 2rst. The loss was held to be on plaintiff, since the acceptance was "in the nature of a draft" which is deemed "actual payment, when a reasonable time to receive it in is elapsed." 49 Of course it is easy to see a difference between the writing in Bishop v. Chitty and the usual "payable at" clause. But granted the proposition that the clause is to be taken as an order upon the named banker, the difference is not one of substance. All that is needed more is a small amount of imagination to see that one instrument has been written on the other.

The question was squarely raised in Turner v. Hayden,,$^{50}$ a case decided subsequent to the special legislation above discussed..$^{x}$ It was again urged that a bill accepted payable at a bankers is like a check and the acceptor is discharged "if a prejudice arises from the laches of the holder." But since the statute had said the acceptance was general, from which it followed that a presentment at the place of payment was not required to charge the acceptor, the court could not see how the holder would be guilty of laches if he failed to so present. In fact Lord Ellenborough had said as much in Sebag v. Abitbol, ${ }^{52}$ though in that case it was further found, on

47 Richardson, J., stated the consequences of nonpresentment at the place of payment this way: "[T]he debtor shall stand excused of damages and costs, if he is ready to pay the money at that place, according to his contract; but, that the debt is not lost to the creditor by an omission on his part to demand it there, except, perhaps, in cases where it can be shown that such omission has occasioned damage to the debtor." Ibid., at Igr.

$$
\begin{array}{ll}
{ }_{4}^{8}{ }_{2} \text { Strange II94 (K.B., I743). } & { }^{50} 4 \text { B. \& C. I (K.B., I825). } \\
{ }_{49} \text { Ibid. } & { }^{51} \text { I \& } 2 \text { Geo. IV, c. } 78, \S \text { I (I82I). }
\end{array}
$$

${ }_{52} 4 \mathrm{M}$. \& S. 462 (K.B., $\mathrm{r} 8 \mathrm{I} 6$ ). Of course, if the maker of a note should give the payee, either as collateral security or as conditional payment, a third party note or acceptance, there would equally be no duty to present such paper for payment in order to "charge" the maker. But it is surely clear that a failure so to do might well be deemed negligence on the creditor's part, and discharge the maker to the extent of his loss. 
the assumption that the rule as to checks applied, that the acceptordrawer had suffered no loss due to the holder's delay.

Thus, whatever Parliament may have intended, if anything, upon the express point, the holder was to be absolved from any obligation to seek payment of the banker named by the acceptor. By parity of reasoning the opposite result would seem to follow in the case of a note made payable at a bank. Since the payment clause is deemed an order on the banker, although the point is not codified, and since presentment is necessary under English law to charge the maker of such a note, as above discussed, a failure to present at maturity or within some reasonable time should put any resulting loss on the holder. ${ }^{53}$ It is fair comment, however, to say that no plausible reason exists for any such difference in outcome. The results to follow from making an acceptance payable at a bank should not differ from those where a note has been made so payable.

\section{EARIY LIFe IN AMERICA}

The early cases in this country went directly to the issue of damages. In one of the first, Wolcott $v$. Van Santvoord, ${ }^{54}$ which was a suit on a bill accepted payable at the Bank of Utica, the acceptor demurred on the ground that there was no averment that the bill had been presented at the bank on the day it became payable. According to Chief Justice Spencer, the inquiry therefore was whether presentment was necessary, or whether it was for the defendant "to plead, in bar of the damages, that he was ready at the time and place, when and where the bill became due, to pay it, and that he has ever since been ready, and now brings the money into court to be paid to the plaintiff?"ss It was decided to follow the decision of the Kings Bench in Fenton v. Goundry ${ }^{56}$ particularly since it had been observed in that case by Bayley, J., that the acceptor might have pleaded that he had the money at the day and place appointed, not "in bar of the action, but in bar only of damages. ..." 57

By the time of Wallace v. McConnell,,$^{8}$ the current of authority had

s3 The Canadian Act adopted a middle position, first explicitly requiring presentment at the bank named in the note, and then going on to say that a failure to present at maturity will not discharge the maker, "but if any suit or action is instituted thereon against him before presentation, the costs thereof shall be in the discretion of the court." Rev. Stat. Can. (I927) c. I6, \& I83. See Maclaren, Bills, Notes and Cheques 492 (6th ed., 1940), where the author says after reviewing a number of decisions: "[T]he question is one which calls for clarifying legislation...." In at least one case, however, it was squarely held that the risk of bank failure was upon a holder who had delayed for nearly two months in making presentment. Banque Canadienne Nationale v. Halle, 67 Que. S.C. 554 (I929).

54 I7 Johns. (N.Y.) 248 (18 Ig).

ss Tbid, at 248.

${ }^{56}{ }^{13}$ East 459 (K.B., I8II).

57 Ibid., at 473 .

${ }^{58}$ r3 $_{3}$ Pet. (U.S.) r $_{3} 6$ ( 1839 ). 
clearly taken the direction that no demand is necessary as a condition precedent to recovery against either maker or acceptor upon an instrument payable at a bank. The possibility that a holder" might hazard the entire loss of his whole debt" by a failure to demand payment "at the time and place" specified, if that was ever the alternative, was not to be entertained. ${ }^{9}$ But the court went on to point out that the designation of a place of payment was for the "mutual accommodation" of the parties, and that if a maker on presenting himself at the place of payment should not find the holder present he might "deposit his money to meet the note when presented, and should he be afterward prosecuted, he would be exonerated from all costs and damages, upon proving such tender and deposit."60

What the court meant by the word "damages" it did not say, but if it included loss due to failure of the bank of deposit, the result would be substantially the same as that reached in Bishop v. Chitty. True the reasoning would be different; in the one case the holder must present at the place of payment as if he held a check upon the banker; in the other, where tender has been made by depositing money at an agreed place, the holder must take the risk of any "damage" ensuing from his subsequent delay in making presentment. Certainly it is hard to see how a line can fairly be drawn exonerating the maker, on the one hand, from damages in the way of interest and costs, but, on the other, holding him liable to the still greater damage caused by failure of the bank of deposit. Neither would have occurred but for the holder's failure to ask for his money promptly at the place and time agreed.

According to the Commissioner's Notes ${ }^{6 x}$ the Wallace case was one of the authorities chiefly relied upon when NUL Section yo was drafted. That section, as noted above, ${ }^{62}$ provides simply that no presentment is necessary to "charge" a maker or acceptor, but if the instrument is "payable

59 Ibid., at I5I. It is not clear that anyone ever urged such a proposition, the whole controversy having grown up over the banker's demand in Bowes v. Sanderson, discussed supra, that he not be put to suit when he stood ready at his banking house to pay as agreed. When counsel in Rhodes v. Gent, 5 B. \& Ald. 244 (K.B., I82r), tried to press the doctrine of Rowe v. Young to the point of saying that an acceptor of a time bill would be discharged (as though he were the drawer of a bill), unless payment were demanded at the stated place of payment on the due date, the court was quick to deny the proposition. In fact Best, J., was surprised that the issue had been raised. His point was simply that if a bill is accepted payable at a bankers: "It is like the case of a check, which, if it be held till after the banker fails, will be considered as payment, in case the person giving it had money in the banker's hands at the time." Ibid., at 246-47.

60 Wallace v. McConnell, I3 Pet. (U.S.) I36, I50 (I839).

6x Beutel, Uniform Statutes Affecting Negotiable Paper 23.

${ }^{6}$ Quoted in full, note 5 supra. 
at a special place," the maker's ability and willingness to pay it there "are equivalent to a tender of payment on his part." To what extent this was intended to exonerate the maker in case of damage by bank failure is thus not stated explicitly. It may be significant, however, that the Commissioners also cited Lazier $v$. Horan, ${ }^{6_{3}}$ with apparent approval in support of the section. That was a case where the maker, as suggested in Wallace v. MCConnell, deposited the amount of his note at maturity with the bank where it was stated to be payable. Some nine months later, and before the note had been presented, the bank failed. The court's holding that the maker was discharged indicates, at least, that NII Section 70 should be generously construed.

But the opposite view had strong support. One of the first cases was Wood \&. Co.v. Merchants' Savings, Loan \& Trust Co. ${ }^{64}$ Here the note, which was made payable "at the banking house of J. G. Conrad, Chicago," had actually been presented to Conrad when due and marked "good" by the teller, but no money was paid out, notwithstanding the maker had on deposit funds sufficient for the purpose. On the next day Conrad failed. It was urged that, since the holder had thus been given "the right and opportunity" of receiving money, according to banking custom, the loss should fall on the holder. But Justice Breese for the court said that "the custom sought to be established among bankers has nothing, in our judgment, to do with the question." In the first place "the holders of this note were under no obligation to present this note at Conrad's counter," and the circumstance that they had done so made no difference, because "the fact that the note was made payable at Conrad's bank, did not authorize that bank to pay the note without being so ordered by the maker, verbally, or by check or draft or other writing. ${ }^{366}$ Custom or no custom, the loss must fall on the maker, though he might not be saddled with costs if he paid his money into court.

Whatever else may be said of this case it no doubt accounts for at least some of the "western" practice mentioned above. It would be a hardy banker, indeed, who, after this decision, would entertain any idea of paying a customer's notes or acceptances without first getting special authority. Justice Breese evidently was not familiar with the view in other parts of the country, as in England, that by making an instrument payable at a bank it is intended thereby to give the banker an authority to pay, quite

\footnotetext{
${ }^{63} 55$ Iowa 75,7 N.W. 457 (1880).

${ }^{64} 4$ I Ill. 267 (I866).

65 Ibid, at 269 .
}

${ }^{66}$ Ibid., at $270-7$ r. 
as much as if a separate check or verbal order had been given: ${ }^{67}$ But it too may very well have been irrelevant in his judgment as was the practice on LaSalle Street. ${ }^{68}$ Nonetheless, the decision was an influential one in shaping the law of neighboring states, and hence of establishing so-called "western" practice. It does not follow, though, either that the practice is sound, or that it cannot be changed.

\section{LIFE UNDER THE STATUTE}

The idea that an instrument payable at a bank is equivalent to a check on the banker has received rough treatment under the NIL. ${ }^{69}$ For the most part it has simply been ignored. But in Binghampton Pharmacy v. First Nat'l Bank, ${ }^{70}$ the position under the statute was well stated. Counsel pointed out that the note in suit had been made payable at the Chickasaw Bank \& Trust Co.; that by NII Section 87 it was therefore an "order" on the bank to pay; that the defendant drawer had sufficient funds on deposit at maturity to make payment and continued to have until the bank failed nine days later; and concluded, therefore, that under NIL Section 186 his client was discharged to the extent of the loss by reason of plaintiff"s delay. But the court said no. In the first place "presentment for payment is not necessary to charge the maker of a note." $7 x$ From

${ }^{67}$ The court in Lazier v. Horan, 55 Iowa $75,80,7$ N.W. 457,459 (r880), quoted, with approval, from Byles on Bills: "If the customer of a banker accept a bill and make it payable at his bankers', that is of itself a sufficient authority to the banker to apply the customer's funds in paying the bill." And, in Grissom v. Commercial Nat'l Bank, 87 Tenn. 350, Io S.W. 774 ( 1889 ), a leading case, which denied the defendant bank any authority to pay plaintiff's note without getting special instructions, there was substantial testimony, though not in agreement on details, that Tennessee banks did pay many notes domiciled with them without seeking further authority.

68 The practice to "mark" notes as good appears to have been regarded much the same as a certification in the case of checks. Compare Willets v. The Phoenix Bank, 2 Duer (N.Y.) x 2I (1853), where the court on similar facts held the bank liable as an acceptor. And, the holder having thus chosen to take the bank's obligation in lieu of cash, the drawer was later to be held discharged. First Nat'l Bank v. Leach, 52 N.Y. $35^{\circ}$ (1873). But Mr. Justice Breese was not inclined to go so far. Consult generally, Steffen and Starr, A Blue Print for the Certified Check, I3 N. C. L. Rev. $45^{\circ}$ (I935).

${ }^{69}$ So careful a commentator as Lile says bluntly that, in the case of a time note or bill of exchange, the "payable at" clause resembles more nearly a bill than a check: "An order on a bank not payable upon demand cannot be a check." Bigelow, Bills, Notes and Checks $25^{8}$ (3rd ed., 1928). But he thought it was really neither a bill or a check, and any attempt to introduce a hybrid instrument, with "no common law ancestry," should be resisted. What Lile would say if the maker of a time note were to give the holder two instruments, one, an ordinary time note, and two, a check post dated to the maturity date of the note, is of course not known. But both instruments would have irreproachable common-law ancestry, and unless the check were presented with dilligence it would seem the drawer-maker would be discharged to the extent of the loss.

${ }^{70}$ I3I Tenn. 7Ir, I76 S.W. I038 (I915). 7 Ibid., at 7 I 7 and 1040. 
which it followed, even as Lord Ellenborough had said in Sebag v. Abitbol, ${ }^{72}$ "such an omission is not laches, and affords the maker no ground of complaint."

The next important casualty occurred in South Carolina. Although in the Zorn case ${ }^{73}$ the court had previously exonerated the maker, it was held in Federal Intermediate Credit Bank v. Epstin ${ }^{74}$ that under the NIL an opposite result was required. Here the note had been made payable "at the Bank of Beaufort," to which it was also payable. And here, as in the Binghampton case, the payee bank had rediscounted the paper before maturity. It was further shown that defendant's account upon the due date was sufficient to pay the note, in fact defendant had given his check to the bank in settlement. The Bank of Beaufort failed some twenty-seven days after the note matured, but plaintiff "did not wake up" 75 until two days later, when it demanded its money. The court listened respectfully, so far as appears, to the argument on NIL Sections 87 and I86, but decided that NII Section 70 should control, ${ }^{76}$ thus putting South Carolina in harmony with other states, as the law was declared in the Binghampton Pharmacy case.

There is nothing to indicate that the majority judges were particularly happy with the result of their decision in the Epstin case. ${ }^{77}$ Judge Cothran, dissenting, was clearly not happy but his main argument came down to the simple proposition that plaintiffs had delayed unreasonably in asking for their money, especially since the payment clause was in effect a check upon the bank: "[T]here can be no doubt that, if the transferee bank had notified the makers that they held the note, the note would have been paid; if it had been presented at the bank, it would have been paid. In all fairness, who should be the loser under this double neglect?'"78 As his second point Judge Cothran suggested that the effect of depositing money

${ }^{72} 4$ M. \& S. 462 (K.B. I8I6).

73 Bank of Charleston v. Zorn, I4 S.C. 444 (1880).

${ }^{74}$ I5 S.C. 67, I48 S.E. 7 r3 (1929).

75 Ibid., at 80, 7I7.

${ }_{70}$ Perhaps it should be pointed out that NIL $\S 70$ is a general provision stating the rule applicable whenever an instrument is "payable at a special place," while NUL $\S 87$ is limited to the particular case where the instrument is "payable at a bank." From this it would follow that the court should so construe the statute as to give full and appropriate meaning to each section.

77 The result was approved in 16 Va. L. Rev. 183 (I929), and disapproved in $x 8$ Calif. L. Rev. 56 (rg29), 29 Col. L. Rev. 1023 (r929), 8 N.C.L. Rev. r84 (1930), and 39 Yale L. J. 277 (I929).

$7^{8} \times 5 x$ S.C. $67,8 \mathrm{x}, \mathrm{x}_{4} 8$ S.E. $77_{3}, 77_{7}\left(\mathrm{x}_{929}\right)$. 
with a bank to meet a note is closely analogous to giving the holder a "collateral security" for its payment. In such case it is well established that a holder "whose negligence has led to a dissipation of the collateral should suffer the loss occasioned thereby."79 Arguments aplenty, but the decision went the other way.

In the case of Adams v. Hackensack Improvement Commission, ${ }^{80}$ a new tack was taken to put the loss of bank failure upon the maker. The instruments in question were bonds and interest coupons to be paid "at the Bank of Bergen County" at Hackensack, N.J. Again, as in the Epstin and Binghampton cases, the maker had no way of knowing who the holders were, but it had duly deposited the necessary funds with the bank for payment prior to maturity. Some eleven days later the bank failed. After a review of the cases in the Rowe v. Young controversy, from which the court concluded that no presentment is necessary as a condition precedent to recovery from a maker, it announced that the only question before it was simply one of agency: "As the custodian of the money wherewith to pay, whose agent is the banker?"8r This was a fatal question, because one would have to agree that "the naming of a bank in a promissory note as the place of payment, does not make the banking association an agent for the collection of the note or the receipt of the money." Hence, there is no escape; the loss must be put on the maker.

It might be observed that, were one to ask the same question in the case of a check, the answer surely would be that the bank was not the agent of the holder. Hence it would seem that on agency principles-if that were all that were involved-the drawer must assume the risk of bank failure. Of course, in no very real sense is the bank an agent of either drawer or holder; it simply is a depository with money available for the holder to demand in payment of the drawer's obligation. ${ }^{82}$ It ordinarily has been designated quite as much for the holder's convenience as for that of the maker. The real question, therefore, is whether the holder should be put under some effective sanction to get his paper to the bank with ordinary business diligence. But it must be said that the "agency": argument has been effective. It served in Iowa to overrule Lazier 7. Horan..$^{8_{3}} \mathrm{It}$ has been at the bottom of a series of bond and coupon cases since the NIL, though

79 Ibid., at 82 and 718.

${ }^{80} 44$ N.J. Law 638 (I888).

${ }^{8 x}$ Ibid., at 646 . The court generously credits the case of Williamsport Gas Co. v. Pinkerton, ${ }_{9.5} \mathrm{~Pa} .62$ (r880), which also was a suit upon interest coupons, with anticipating it in the use of the "agency" argument.

82 Cases may be cited ad infinitum to the point that the relation between bank and depositor is that of debtor and creditor. Foley v. Hill, 2 H.L.C. 28 (I848).

$8_{3}$ Bank of Montreal v. Ingerson, IO5 Iowa 349, 75 N.W. 35 I (1898). 
NII Section 70 has also played its part-which have held that loss due to failure of the depository bank must fall upon the issuer, not the dilatory holder. ${ }^{84}$

The "agency" argument, of course, is one that can be worked both ways. In Morley v. University of Detroit, ${ }^{85}$ the action was upon bonds and interest coupons issued by defendant under a trust indenture. The court conceded at once that under NIL Section 70 no presentment was necessary to charge the issuer. And that ordinarily the fact that the issuer had deposited funds with the Fidelity Trust Company, where the instruments were made payable, would be immaterial. Should loss ensue it must be at the risk of the maker. It then went on to point out, however, that under the indenture before it the trustee was given considerable authority "to receive payments and distribute them among the bondholders." 86 This could be made out as an "agency." Accordingly the shoe was on the other foot, and the plaintiff security holder must lose. ${ }^{87}$

So far so good; but the "agency" approach reaches a strange result in another situation. In Baldwins Bank of Penn Yan v. Smith ${ }^{88}$ the holder had been diligent and lodged his note at maturity with the bank at which it was payable. The maker also was diligent, as he telephoned to the bank at maturity with instructions to pay, but this would seem not to change the situation as the "payable at" clause was itself a sufficient order. In the opinion of Judge Miller, "the failure to secure payment was due to the neglect of the plaintiff's agent, and the loss resulting therefrom should fall on the one responsible for the fault." 89 This outcome is strange for

\footnotetext{
${ }_{4} 4$ Employers Mut. Ins. Co.v. Board of County Com'rs, ro2 Colo. I77, 78 P. (2d) 380 (r937), noted with approval 37 Mich. I. Rev. 64r (x939); Sherlock v. Duck Creek, 338 Mo. 866, ${ }_{92}$ S.W. (2d) 675 (1936); Mershon v. Millerstown Borough, I28 Pa. Super. 248, r93 Atl. 328 (1937); Mullen Beverage Corp. v. School Dist., 99 Mont. 388, 43 P. (2d) 902 (I935). In the latter case Morris, J., dissenting, said, at 906: "The question involved here is, in my opinion, one of negligence rather than of statutory construction, and the majority opinion rewards the slothful and negligent, and penalizes the diligent."
}

${ }^{85} 263$ Mich. I 26, 248 N.W. 570 (I933). The decision was criticized by Aigler, Bills and Notes-Bonds Payable at Office of Trustee which Becomes Insolvent after Due Date but before Bonds Presented, 32 Mich. L. Rev. 232 (r933). It was afterward carried to the Supreme Court, and, when certiorari was denied, 294 U.S. 718 (I935), was heard on the merits and affirmed, 269 Mich. 216, 256 N.W. 86I (I934).

${ }^{86} 263$ Mich. I26, I29, 248 N.W. 570, 57 I (I933).

${ }^{87}$ Adler v. Hot Springs, 209 Ark. 400, I90 S.W. $2 d 528$ (I945); Adler v. Interstate Trust \& Banking Co., I66 Miss. 215, I46 So. I07 (I933); Manchester v. Sullivan, I12 Conn. 223, I52

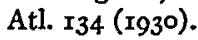

${ }^{88}{ }_{215}$ N.Y. 76, I09 N.E. I38 (IgI5), noted in 29 Harv. L. Rev. 204 (IgI5) and 14 Mich. L. Rev. $5^{8}$ (I9I5).

${ }^{89}{ }_{215}$ N.X. 76, rog N.E. ${ }_{3} 8$ (IgI5); cf. Scott County Milling Co. v. Weems, I 79 Ark. 935, I9 S.W. 2d ro27 (r929); Shaw v. Flick Mercantile Co., 26 S.W. 2 d ro77 (Tex. Civ. App., 1930). 
had the plaintiff done nothing whatever for weeks, he could under present law still recover of the maker the full amount of his obligation, less interest and costs. Thus in truth does the law penalize the diligent and reward the slothful.

\section{LOOKING TO THE FUTURE}

The day is past when one may profitably argue that some court or other in the foregoing journey may have taken a wrong turn, and that the law is really otherwise. The question now is, what should the legislature do? Enough has been said, however, to indicate that the present law is not exactly the perfect resultant of an infallible process. Actually the courts and legislatures have built with blocks which did not readily lend themselves to nice adjustment. ${ }^{\circ}$ "Should they say that the "payable at" clause is just like a "check" or a "bill"? Is the money in bank in the nature of a "collateral security"? Has the maker by being able and willing to pay made a "tender"? Is the bank perhaps an "agent" of one party or the other? The finished structure made by selecting from only such materials, while livable, cannot well be good architecture.

The concept that a "tender" is made by drawing an instrument payable at a bank-if the maker has funds on deposit at maturity-is particularly disturbing. It harks back to primitive times when maker and holder would actually go in person to the place of payment to settle their affairs. Perhaps it was a step in advance, because it substituted the bank for the maker, in case the parties did not attend. But it surely has been a great many years since any one has expected that the parties would meet in person at the bank. ${ }^{9 x}$ Paper of this sort goes through regular banking channels and, in the usual case, is paid in due course.

Actually, therefore, the maker has done much more than make a simple personal tender. He has given the payee an instrument by which he, or any subsequent holder, may readily avail himself of the money on deposit. For the "mutual convenience" of the parties he has put the funds in the hands of a third person, a bank, not always of his selection. The situation is thus so far different from a direct personal tender that it would seem a different rule should apply. Whether to adopt the commonlaw rule of prompt presentment applicable to "checks," without modification, however, is also a debatable matter. But if the alternative were

${ }^{\circ}$ Consult Levi, An Introduction to Legal Reasoning, 15 Univ. Chi. L. Rev. 5or (I948).

${ }_{9 x}$ Even in I880 the court in Lazier v. Horan, 55 Ia. 75, 80, 7 N.W. 457,460 , recognized this fact: "The parties to the note did not contemplate that the payee should make a journey from Indianapolis and meet the maker at Allen's bank, and there receive his money from the hands of the maker and deliver him the note." 
that makers generally would leave their money on deposit for one day only-thus making a tender within NLL Section 70-the check rule should be favored. ${ }^{92}$ For the sense of the thing is surely that the maker should leave his money for at least a reasonable time, so that the holder may make collection. Indeed, he should be encouraged to leave his funds with the bank thereafter until called for, but the dilatory holder should pay for the service by assuming the risk. The mechanism must be so adjusted that an optimum number of payments will go through with a minimum of unnecessary delay and risk.

Turning then to the proposed Commercial Code, what do we find? In the first place NIL Section 70 is still in full vigor: "Where the maker or acceptor is able and ready to pay at every place of payment specified in the instrument when it is due, it is equivalent to tender." 93 The consequence of failure to present is now expressly stated to be that the maker "is discharged to the extent of all subsequent liability for interest, cosis and attorney's fees." 94 While the maker or acceptor is thus given his attorney's fees, in addition to the common-law provision for interest and costs, it would seem the door is closed quite firmly on any argument that "loss" or "damage" due to failure of the bank can be charged to the dilatory holder. But, as pointed out above, this is a general provision and applies even where the maker or acceptor has specified that he would pay in person at a local tavern. The provision surely affords such a maker, "able and ready to pay" if found, all the protection to which he is entitled. In fact more, for the attorney fee provision is dubious in any case.

The section expressly dealing with instruments payable at a bank gives at least a toe hold. The new version of NUL Section 87 , that is, Uniform Commercial Code Section 3-I22, Alternative $A$, above referred to, says that a note or acceptance payable at a bank "is the equivalent of a bill drawn on the bank payable when it falls due...." Here, then, is something which counsel in the Binghampion Pharmacy"s case could have used with telling effect. If the "payable at" clause is the equivalent of a

${ }^{2} \mathrm{It}$ is argued in Bigelow, Bills, Notes and Checks 260 (3rd ed., 1928), that all that is required of a maker or acceptor is that he have his funds at the place of payment for one day. That constitutes a tender within NIL $\S 70$. Hence the maker, by permitting the funds to remain on deposit thereafter, "assumes the risk of the bank's solvency." But in the case of a check it is pointed out "it is the duty of the drawer to be and to remain in funds with the bank" (italics omitted). While this reasoning may accord with present law it is submitted that the maker or acceptor likewise should be expected to remain in funds until payment, but at his own risk for only a reasonable time.

${ }_{93}$ UCC \& 3-604 (3).

$94 \mathrm{UCC} \S 3-604(\mathrm{x})$.

95 Binghampton Pharmacy v. First Nat'l Bank, I3I Tenn. 7II, I76 S.W. Io38 (19I5). 
"bill"-though surely the word "draft" was intended"6-then it would follow that unless the note were duly presented at maturity and proper notice of dishonor were given, the drawer, i.e. maker, would be completely discharged. ${ }^{97}$ That would be going further than any one has yet suggested.

But not so fast; it appears the rule as to discharge of "drawers" has also been changed. It is now provided ${ }^{98}$ that where delay occurs in making any "necessary presentment" the drawer may satisfy his obligation by assigning over to the holder his rights against the drawee bank in respect of the funds maintained for payment of the item. ${ }^{99}$ Thus we are back to the check rule, much as it is stated in NII Section 186 , which undoubtedly would have pleased Judge Best, who urged the point long ago in Rowe v. Young. That is, this is so if presentment is "necessary" in the case of a note payable at a bank. But that too, it seems, is a matter of argument. Certainly, qua maker, no presentment is necessary, but qua drawer presentment would be required under the Code. ${ }^{.00}$ Whether the "maker" of a note payable at a bank is also a "drawer" for this purpose the Code does not say.

The situation is confused. But suppose the word "check" were to be substituted for "bill"? or "draft" in the proposed Alternative $A .{ }^{\text {xox }}$ Again we find a change has been made. The ancient rule requiring diligent presentment of checks, under penalty of taking the risk of the drawee bank's failure, has been replaced with a flat thirty-day provision. ${ }^{\mathrm{x}}{ }^{\mathrm{az}}$ That is, it is proposed to give the holder thirty days after issue in which "to present for payment or to initiate bank collection." ${ }^{\text {103 }}$ Surely the draftsman has been unduly generous. It is true, we are not as nervous now as we once were about bank failures, but failures still occur and by no means all

${ }^{96}$ As the commercial paper article of the Code is now drafted the word "bill" does not appear except in this provision. The word "draft" has been substituted throughout. It is suggested, without diffidence, that there also should be a provision to the effect: "A draft is a bill of exchange."

97 NIL $\S 70$.

${ }_{98} \mathrm{UCC} \S 3-502(\mathrm{x})(\mathrm{c})$.

99 As applied to the drawer of a check this is an improvement on NII $\S$ I86, which merely provided that the drawer would be discharged "to the extent of the loss caused by the delay." Compare Bills of Exchange Act $\S 74(\mathrm{r})$. Since it was usually impossible to ascertain what the loss was at any given time the courts were prone to discharge drawers completely. Seager v. Dauphinee, 284 Mass. 96, I 87 N.E. 94 (I933).

roo UCC $\& 3-501$ (4)(a).

sor See text at notes 8-9 supra.

102 UCC $\S 3-503(2)(a)$.

${ }^{\text {ro3 }}$ Ibid. It will be noted that the holder is only required to "initiate" bank collection. 
deposits are covered by insurance. It would seem, in fact, that ten days at most would be adequate, ${ }^{304}$ unless there is some social purpose whose virtue is not readily apparent in shifting from creditors to drawers the losses due to bank failures. ${ }^{\text {xos }}$

The sum and substance of the matter is that special provision should be made in the Code for paper "payable" at a bank. It will not do simply to describe such an instrument as an "order," or a "bill"' or "check." Paper payable at banks is here to stay and should be given explicit recognition. The writer, therefore, would suggest that the substance of two simple propositions be adopted, as follows:

r. A note or acceptance which states that it is payable at a bank is an order upon the bank to pay the instrument out of funds available in current account or otherwise.

2. Where the bank is ready and able to pay the instrument when due or within ten days thereafter, and the holder fails to make presentment for payment or to initiate bank collection within such time, the maker or acceptor may in event of the subsequent insolvency of the bank discharge his liability upon the instrument by written assignment to the holder of his rights against the bank with respect to the funds maintained with the bank as cover for the instrument.

The first suggestion is simply to state what has been true in nearly all jurisdictions for a century or more. ${ }^{\text {06 }}$ Where a different "practice" prevails, there is no reason in the world why it may not continue as in the past. Notwithstanding the instrument is an order upon the banker, the latter may, as he often does even in the case of checks, call up his customer and ask if payment is in order. It should be pointed out, moreover, that unless such a provision is in effect it is very difficult to see how the fact that the maker may have had funds on deposit to meet the note can ever constitute a "tender." This is for the reason that the maker must have been "able and willing," or as the new version of NIL Section 70 has it, "able and ready," ${ }^{\text {ro7 }}$ when the instrument fell due. Clearly, if no presentment is made at maturity, and the banker has been given no order to pay, the maker or acceptor cannot in any realistic sense say that he was ever either

xo4 In ro days a holder can surely get his paper into a bank for collection. At the same time, by giving a fiat period such as ro days, there will be eliminated a great many cases on close questions concerning what is a reasonable time.

ros Consult Turner, Deposits of Demand Paper as "Purchases," 37 Yale L. J. 874 (Ig28).

${ }^{106}$ Aetna Nat'l Bank v. Fourth Nat'l Bank, 46 N.Y. 82 ( $187 \mathrm{I}$ ). Moreover, there is no good reason why the order should be limited to the day of maturity. Under NII $\S 88$ a bank, of course, could not safely pay so-called "stale" paper without further reference to its customer. But the drawing would still be an order. Perhaps there should be drafted a definite time section to specify where such paper gives notice of equities, say after 30 days. Certainly the blanket exemption from all responsibility, UCC $\$ 3-603$, now proposed for the paying banker, should be condemned.

ז07 UCC \& 3-604(3). 
"willing" or "ready" to pay. What he would have done had the bank asked for instructions is pure conjecture.

The second suggestion gives the holder adequate time, ten days, in which to take his note or acceptance to the stated bank, or to initiate bank collection. During such time it would seem the maker or acceptor should stand responsible for the solvency of the bank. But if, for his own convenience, the holder sees fit to sleep on his rights thereafter, surely any subsequent loss due to bank failure should be his. This is not to say that the instrument is a "check" security," but it does state a position in harmony with the deepseated feeling, inherent in those terms, that a creditor must exercise ordinary business care and diligence or his debtor should be discharged to the extent of his loss. ${ }^{\text {Tog }}$ The result is good commercial sense.

${ }^{108}$ Of course, the position of the bank is substantially that of a drawee, and that of the maker or acceptor, of a drawer. In fact, in order fully to welcome the s"payable at" instrument into the Code there should be further recognition of this point.

${ }^{209}$ The present suggestion does not deal with the demand instrument, check, note or acceptance, nor does it reach to bonds and coupons; the latter are governed by Article 8 of the Code, which deals with investment instruments, though there is no provision on the question herein discussed. 